\title{
Prokrastynacja - struktura konstruktu a stosowane skale pomiarowe
}

\author{
Iga Jaworska-Gruszczyńska ${ }^{1}$ \\ iga.jaworska@gmail.com \\ Uniwersytet Wrocławski
}

\begin{abstract}
Niniejsza praca poświęcona jest zjawisku prokrastynacji i konstrukcji kwestionariusza badającego zwlekanie. Ze względu na brak polskich badań praca powstała głównie w oparciu o dostępne w internetowych bazach EBSCO artykuły naukowe autorstwa najważniejszych badaczy zajmujących się tą tematyką, $\mathrm{m}$. in. J. R. Ferrariego, C. H. Lay’a, H. C. Schouwenburga, E. D. Rothblum, L. J. Solomon, L. Manna, P. Steela, T. Pychyla. Punktem wyjścia jest przegląd zagadnień teoretycznych, stanowiący wstęp do prezentacji badań własnych. Badania przeprowadzono na próbie 160 ochotników, którzy wypełnili cztery połączone skale - General Procrastination Scale, Adult Inventory of Procrastination, Tuckman Procrastination Scale, Aitken Procrastination Inventory. Na uzyskanych danych dokonano analizy czynnikowej oraz hierarchicznej analizy skupień, wyłaniając 40 pozycji tworzących końcową wersję Kwestionariusza Zwlekania (KZ). Skonstruowana skala zawiera pięć podskal i służy do oceny ogólnego poziomu prokrastynacji oraz pięciu jej aspektów (umiejętność organizacji czasu, siła woli, świadomość prokrastynacji, zwlekanie jako cecha, niepunktualność), a w przyszłości może umożliwiać tworzenie indywidualnych profilów zwlekania osób badanych. Kwestionariusz uzyskał wysoki współczynnik zgodności wewnętrznej alfa Cronbacha 0,971 . Analiza sprawdzająca wartość diagnostyczną skali wykazała, że stanowi ona dobre źródło hipotez zarówno badawczych, jak i klinicznych na temat przyczyn i charakterystyki zwlekania osób o różnych poziomach prokrastynacji ${ }^{2}$.
\end{abstract}

\section{Wprowadzenie teoretyczne}

Prokrastynacja znana była już starożytnym Babilończykom, Grekom i Rzymianom. Kodeks Hammurabiego starał się przed nią zabezpieczać, ustalając terminy składania zażaleń (Knaus, 2007, s. 16-17), natomiast poeta Hezjod (2011, s. 23) przestrzegał w Pracach

\footnotetext{
${ }^{1}$ Tekst powstał na podstawie pracy magisterskiej pt. „Prokrastynacja - struktura konstruktu a stosowane skale pomiarowe" przygotowanej pod kierunkiem prof. dr. hab. Władysława Jacka Paluchowskiego i recenzowanej przez dr. hab. prof. UWr. Marię Straś-Romanowską.

${ }^{2}$ Pełna wersja Kwestionariusza Zwlekania dostępna jest u autorki (iga.jaworska@gmail.com).
} 
i dniach, że odkładanie niezbędnych czynności prowadzi jedynie do strat i problemów: „Czas tylko stracisz na próżno i wynik twej pracy się zmniejszy; / Jej nie odkładaj na jutro lub nawet na dzień gdzieś późniejszy. / Człowiek leniwy lub ten, co odkłada robotę, komory / Swej nie napełni, lecz pilność jedynie powiększy ci zbiory. / Kto opieszały jest w pracy, ten nigdy z kłopotów nie wyjdzie”. Jako jedną z najgorszych cech ludzkich piętnowali zwlekanie także Tukidydes i Cyceron. W kręgu kultury europejskiej prokrastynacja zyskała jednak szczególnie negatywną konotację dopiero wraz z nadejściem rewolucji przemysłowej, ok. 1750 roku, gdy nowa organizacja produkcji i zwiększenie tempa pracy sprawiły, że opóźnienia zaczęły mieć poważne konsekwencje dla większej grupy ludzi (Ferrari, Johnson i McCown, 1995, za: Steel, 2007).

Mimo długiej historii istnienia i powszechności zjawiska dopiero w latach 80. XX w. stało się ono przedmiotem systematycznych badań psychologicznych (Freeman, CoxFuenzalida, Stoltenberg, 2011). Współczesne badania pokazują, że prokrastynacja dotyczy około 15-25 procent osób dorosłych i około 70-95 procent studentów (Ferrari, O’Callahan, Newbegin, 2005; Steel, 2007; Knaus, 2007). Mniejszy odsetek prokrastynatorów w dojrzałej populacji Steel (2007) thumaczy uczeniem się i doskonaleniem sposobów przezwyciężania zwlekania oraz uzyskiwaniem większej praktyki w wykonywanych zadaniach. Ferrari i współpracownicy uważają jednak, że wraz $\mathrm{z}$ wiekiem nie zmienia się liczba osób prokrastynujących, lecz jedynie typ przejawianej przez nie prokrastynacji - u ludzi młodszych jest to głównie zwlekanie ograniczone do specyficznych sytuacji, zwłaszcza związane z ich aktywnością szkolną i akademicką, natomiast u starszych - prokrastynacja chroniczna, przejawiająca się w życiu codziennym i przyjmująca postać prokrastynacji unikowej lub związanej z poszukiwaniem pobudzenia.

Nie jest również jasne, czy współcześnie problem prokrastynacji narasta, czy zwiększa się jedynie przyzwolenie na przyznawanie się do zwlekania. Kachgal i współpracownicy (za: Steel, 2007) uważają, że odkładanie na później to kolejny, obok otyłości, hazardu i przesadnego zadłużania się, przejaw niepowodzeń w samoregulacji. Zdaniem badaczy w ciągu ostatnich 25 lat obserwujemy kulturowo uwarunkowany spadek zdolność do efektywnej samoregulacji, co każe spodziewać się rosnących problemów ze zwlekaniem. Steel dopuszcza jednak możliwość, że widoczny wzrost liczby osób angażujących się w zwlekanie ma charakter pozorny i wynika $\mathrm{z}$ samoopisowego charakteru badań nad prokrastynacją. $\mathrm{W}$ istocie zwiększyć miałaby się jedynie swoboda przyznawania się do zwlekania, nie zaś odsetek prokrastynatorów. 


\section{Definicja prokrastynacji}

Słowo ,prokrastynacja” pochodzi od łacińskiego procrastinatio „odroczenie, zwłoka” i oznacza dosłownie „odkładanie na jutro” (łac. pro - „,naprzód”, crastinate - ,jutro”). Istnieje wiele definicji tego zjawiska. Definicja najprostsza ukazuje prokrastynację jako „celowe odkładanie zamierzonego działania" (Ferrari, Barnes, Steel, 2009), akcentując jedynie behawioralne przejawy zwlekania i jego intencjonalny charakter. Formuła ta wydaje się niepełna i zbyt ogólna, umożliwia bowiem włączenie w zakres pojęcia również innych zjawisk, takich jak choćby unikanie podejmowania pochopnych decyzji i działania na ich podstawie, lenistwo czy próżniactwo społeczne.

Ferrari i Pychyl (2012) podają definicję rozszerzoną, według której prokrastynacja to „dobrowolne odwlekanie zamierzonego działania przy wykonywaniu pewnych zadań mimo przewidywanych negatywnych konsekwencji i potencjalnie gorszego wyniku". Sformułowanie to zawiera trzy istotne kryteria prokrastynacji - 1) dobrowolność odwlekanie nie może być zatem wymuszone czynnikami zewnętrznymi, 2) zwlekanie dotyczy działań, czyli konkretnych zachowań związanych z realizacją zadań, 3) osoba prokrastynująca zdaje sobie sprawę z możliwych negatywnych następstw niepodejmowania wymaganej aktywności, lecz świadomość prawdopodobieństwa uzyskania gorszych rezultatów nie motywuje jej do pracy.

Na ważne cechy dystynktywne wskazali Steel i Milgram. Steel (2007) stwierdził, że zwlekanie jest działaniem irracjonalnym - w przypadku prokrastynacji nie ma więc żadnych istotnych przyczyn dla opóźnień. Milgram natomiast podkreślał, że zwlekanie nie jest aktem jednorazowym, lecz serią wielu kroków obejmujących zarówno bezczynność, jak i działania podejmowane w zastępstwie planowanej aktywności, a samo odraczanie i jego rezultat wiążą się z doświadczaniem przykrych stanów emocjonalnych (za: Ferrari, Johnson, McCown, 1995).

Z takim ujęciem definicyjnym polemizują Ferrari, Johnson i McCown (1995). Ich zdaniem prokrastynacja nie zawsze skutkuje gorszym poziomem wykonania. Autorzy ci są przekonani, że istnieje rodzaj zwlekania stanowiący strategię działania osób potrzebujących silnej stymulacji, który dostarcza im właściwego poziomu pobudzenia i motywacji, prowadząc do efektywnego działania. Negują również zasadność uznania doświadczania dyskomfortu jako warunku koniecznego dla rozpoznania prokrastynacji 
(przeczy temu np. wykorzystanie zwlekania jako strategii samoutrudniania, służącej ochronie poczucia własnej wartości i kompetencji prokrastynatora).

Trudności definicyjne wiążą się także $\mathrm{z}$ faktem, że prokrastynacja może być rozumiana zarówno jako określony rodzaj zachowania, jak i cecha osobowości. Rozróżnienie to stosuje Schouwenburg (1992), twierdząc, że prokrastynacja jako cecha jest główną przyczyną behawioralnych przejawów zwlekania, jednak oba zjawiska nie są tożsame. Prokrastynacja jako zachowanie uwarunkowana jest wieloma czynnikami poza osobowościową skłonnością do odraczania. Wsparciem dla spostrzegania prokrastynacji jako cechy jest jej stabilność w czasie i w odniesieniu do różnorodnych typów sytuacji oraz częściowe uwarunkowanie genetyczne, wyjaśniające około 22 procent jej zmienności (Steel, 2007).

W literaturze przedmiotu wyróżnianych jest kilka rodzajów prokrastynacji. Zostaną one kolejno omówione.

\section{Rodzaje prokrastynacji}

Najbardziej popularny model prokrastynacji, zaproponowany w 1992 r. przez Ferrariego, wyróżnia trzy podstawowe jej rodzaje - unikową (avoidant procrastination), związaną z poszukiwaniem pobudzenia (arousal procrastination) oraz decyzyjną (decisional procrastination).

Prokrastynacja unikowa to „odraczanie zadań, których wykonanie odzwierciedla umiejętności” (Ferrari, O’Callaghan, Newbegin, 2005). Jednostka przekonuje tu siebie i innych, że doznane niepowodzenia są wynikiem braku odpowiedniego wysiłku włożonego w pracę lub presji czasu, nie zaś braku zdolności. U podłoża tego rodzaju prokrastynacji leżą lęk przed porażką i lęk przed ujawnieniem własnych słabości, a zwlekanie służy ochronie poczucia własnej wartości (Díaz-Morales, Cohen, Ferrari, 2008).

Prokrastynacja związana $\mathrm{z}$ poszukiwaniem pobudzenia to odkładanie wykonania zadania do ostatniej chwili w celu doznania przyjemnego dreszczu emocji wywołanych zmaganiem się z presją czasu. Ten rodzaj zwlekania łączy się z poszukiwaniem doznań (szczególnie z podatnością na nudę), niskim poczuciem własnej wartości, niskim poczuciem własnej skuteczności oraz impulsywnością (Freeman, Cox-Fuenzalida, Stoltenberg, 2011). Zazwyczaj prokrastynacja prowadzi do gorszego wykonywania zadań niż systematyczna i sumienna praca, jednak zwlekanie podejmowane w celu uzyskania przyjemnego dreszczu 
emocji może, zwłaszcza u niedostymulowanych ekstrawertyków (zgodnie z teorią Eysencka) skutkować dobrymi wynikami, gdyż działaniu tuż przed upływem terminu towarzyszy optymalny, nie zaś zbyt wysoki poziom pobudzenia (Freeman, Cox-Fuenzalida, Stoltenberg, 2011).

Koncepcja prokrastynacji decyzyjnej wywodzi się $\mathrm{z}$ konfliktowego modelu podejmowania decyzji Janisa i Manna (Mann, Janis, Chaplin, 1969; Orellana-Damacela, Tindale, Suárez-Balcázar, 2000; Beswick, Rothblum, Mann, 1988), który zakłada, że podejmowanie decyzji jest działaniem stresującym i wiążącym się ze znaczną niepewnością. W trakcie dokonywania wyboru osoba radzi sobie ze stresem poprzez poszukiwanie i ocenę dostępnych rozwiązań alternatywnych. Gdy żadna alternatywa nie jest satysfakcjonująca lub wszystkie dostrzegane możliwości są ryzykowne, osoba stojąca przed koniecznością dokonania wyboru może uciekać od podejmowania decyzji poprzez prokrastynację.

Prokrastynacja unikowa i związana z poszukiwaniem pobudzenia zwykle ujmowane są łącznie jako typy prokrastynacji behawioralnej i odróżniane od prokrastynacji decyzyjnej. Prokrastynacja unikowa i związana z poszukiwaniem pobudzenia bywają również łączone jako przejawy prokrastynacji chronicznej (chronic procrastination) i przeciwstawiane prokrastynacji akademickiej (academic procrastination) lub zwlekaniu specyficznemu sytuacyjnie (situational-specific task delays).

Chroniczna prokrastynacja to według Ferrariego i jego współpracowników (Ferrari, O'Callaghan, Newbegin, 2005) nieadaptacyjny styl życia, częste, niemal chroniczne opóźnianie realizacji zadań, wiążące się z angażowaniem się w aktywności o charakterze samoutrudniającym, dbaniem o wywieranie pozytywnego wrażenia i unikaniem oceny własnej osoby. Jak podają Díaz-Morales, Ferrari i Cohen (2008) chroniczni prokrastynatorzy preferują krótkoterminowe, przyjemne aktywności i natychmiastowe nagrody, uzyskiwane nawet kosztem niepowodzeń w osiąganiu odleglejszych celów.

Dokonana przez Steela (2010) metaanaliza 17 badań nie potwierdziła trójdzielnego modelu Ferrariego. Zakwestionowane zostało zwłaszcza rozróżnienie na prokrastynację unikową (mierzoną według Ferrariego skalą AIP McCowna i Johnson) i związaną z poszukiwaniem pobudzenia (mierzoną skalą GPS Lay'a). Korelacja pomiędzy skalami AIP oraz GPS wyniosła 0,71 i 0,86 , była więc znacząco silniejsza niż uzyskana w badaniach Ferrariego $(\mathrm{r}=0,07, \mathrm{~K}=3, \mathrm{~N}=326)$ i wskazywała raczej na paralelność obu testów. Potencjalnie inny rodzaj zwlekania mierzony jest skalą DPQ Manna, która korelowała ze 
skalą AIP na poziomie 0,57 i ze skalą GPS na poziomie 0,71 , a ponad połowa jej wariancji okazała się unikalna dla niej samej.

Alternatywne wobec modelu Ferrariego ujęcie stanowi model Milgrama i Tenne (2000). Wyróżnia on cztery główne rodzaje prokrastynacji: 1) akademicką (academic procrastination; prokrastynację „studencką"), 2) codzienną (life routine procrastination), 3) decyzyjną (decisional procrastination) oraz 4) kompulsywną (compulsive procrastination), czyli występowanie u tej samej osoby prokrastynacji decyzyjnej i codziennej. Poniżej przedstawione zostaną dwa pierwsze typy zwlekania. Są to zarazem rodzaje prokrastynacji, co do których odrębności i sensu wydzielania istnieje największa zgoda w środowisku badaczy.

Prokrastynacja akademicka to opóźnienia w wywiązywaniu się z zadań akademickich oraz związany z nimi dyskomfort (Milgram, Marshevsky, Sadeh, 1995), które prowadzą do uzyskiwania gorszych wyników w nauce. Badania Solomon i Rothblum (1984) ujawniły, że prokrastynacja akademicka powodowana jest głównie dwoma czynnikami: lękiem przed porażką oraz, w drugiej kolejności, awersyjnością zadania. U studentów zwlekających z obawy przed niepowodzeniem przyczyna ta wyraźnie dominuje, łącząc się z lękiem przed oceną, perfekcjonistycznymi standardami wykonania oraz niską pewnością siebie. Studenci zwlekają, gdyż nie są w stanie spełnić własnych wygórowanych oczekiwań lub dlatego, że koncentrują się na złych wynikach. Awersyjność zadania rzadko stanowi jedyną przyczynę prokrastynacji, osoby na nią wskazujące tworzą zatem grupę bardziej heterogeniczną. Spostrzeganie zadania jako nieprzyjemnego wiąże się przede wszystkim $\mathrm{z}$ niechęcią do angażowania się w czynności akademickie oraz brakiem energii, ale również z trudnościami w podejmowaniu decyzji i zarządzaniu czasem.

Prokrastynacja codzienna to doświadczanie trudności z tworzeniem harmonogramu uwzględniającego czynności dnia codziennego i przestrzeganiem tego rozkładu (Milgram, Sroloff, Rosenbaum, 1988). Osoby nieprokrastynujące w życiu codziennym traktują wykonywanie rutynowych zadań jedynie jako środki służące osiągnięciu określonych celów w ważnych obszarach życia. Mając świadomość nadrzędnych celów, stosują strategie wzmacniające samoregulację, przezwyciężają osobistą niechęć do pewnych czynności, wykonują je szybko i przechodzą do istotniejszych i bardziej przyjemnych aktywności. Prokrastynatorzy natomiast spostrzegają codzienne zajęcia jako nieprzyjemne i wymuszone oraz dążą do innego celu - samopotwierdzenia (self-assertion) uzyskiwanego poprzez biernoagresywny opór. Konsekwentnie wyrażają sprzeciw, nie bacząc na skutki swoich zachowań. 
„Prokrastynacja wzmacnia u nich złudzenie panowania nad pewnymi aspektami własnego życia, nieważne że trywialnymi i mało istotnymi” (Milgram, Sroloff, Rosenbaum, 1988).

W. J. Knaus (2007) wyróżnił dwa podstawowe wzorce prokrastynacji odbywające się w przestrzeni życia codziennego - zwlekanie społeczne, obejmujące „opóźnienia wywierające wpływ na otoczenie", czyli dotyczące różnego rodzaju społecznych zobowiązań, oraz zwlekanie osobiste, wpływające przede wszystkim na osobę prokrastynującą i dotyczące głównie odkładania na później spraw związanych z samorozwojem. Zwlekanie społeczne i osobiste może, zdaniem Knausa, odbywać się według jednego z siedmiu stylów, do których należą: 1) zwlekanie łagodne w skutkach, polegające na odkładaniu do załatwienia w późniejszym terminie „spraw ważnych, ale nie najważniejszych”, 2) zwlekanie życzeniowe, wiążące się z niedotrzymywaniem złożonych sobie obietnic, 3) zwlekanie behawioralne, czyli trudności z podjęciem konkretnych, ale spostrzeganych jako nużące i nieciekawe działań służących osiągnięciu zaplanowanego celu, 4) efekt jo-jo, czyli zwlekanie według schematu „Zwlekanie - działanie - zwlekanie - działanie”, 5) spóźnianie się, wynikające z angażowania się w czynności poboczne, nieuwzględniania w planach czasu przygotowań, awersją do czekania, itp., 6) zwlekanie utrudniające, czyli intencjonalne powodowanie opóźnień, aby uprzykrzyć życie innym ludziom oraz 7) ogólny nawyk zwlekania, nie mający jednej przyczyny, lecz będący efektem interakcji różnych procesów psychologicznych, takich jak brak wiary w siebie, uciekanie przed dyskomfortem, obrona przed lękiem, porażką lub wstydem.

\section{Wybrane teorie wyjaśniające zjawisko prokrastynacji}

Aby wyjaśnić zjawisko prokrastynacji, badacze odwołują się najczęściej do dwóch teorii - Teorii kontroli działania Juliusa Kuhla oraz Poznawczo-transakcyjnego modelu stresu i radzenia sobie Richarda Lazarusa i Susan Folkman.

Teoria Kuhla (Strelau, Doliński, 2008; Kadzikowska-Wrzosek, 2010) pozwala rozpoznać przyczyny prokrastynacji, do których należą przede wszystkim: 1) słaba motywacja, zwłaszcza u osób o niskiej motywacji osiągnięć lub wątpiących ze własne kompetencje, 2) znaczna liczba możliwych do podjęcia działań alternatywnych i siła ich przyciągania, co ma szczególne znaczenie dla ludzi neurotycznych, impulsywnych, o niskiej tolerancji na frustrację i zdolności odraczania gratyfikacji, 3) niewielka zdolność regulacji afektu - dotyczy to przede wszystkich jednostek neurotycznych, doświadczających znacznej 
liczby różnorodnych emocji negatywnych, 4) ograniczony dostęp do pamięci rozciągłej i wynikający z tego brak wglądu we własne potrzeby i preferencje, co może nasilać skłonność do reaktancji u osób o niskiej ugodowości. Zgodnie z teorią kontroli działania prokrastynują głównie jednostki zorientowane na stan, niezależnie od ich indywidualnych charakterystyk osobowościowych, jednak pewne układy cech mogą predysponować do przyjmowania orientacji na stan, a co za tym idzie - do zwlekania.

Teoria Kuhla wyjaśnia także istnienie odmiennych rodzajów prokrastynacji (Milgram, Tenne, 2000). Podejmowanie decyzji jest aktywnością poprzedzającą działanie i polegającą na wybieraniu takiego zachowania, które byłoby w jak największym stopniu zgodne z systemem wartości, potrzebami i preferencjami osoby. Trudności decyzyjne wiążą się zatem z dysfunkcją procesu samoregulacji. Gdy cel zostanie wyznaczony, główne zadanie polega na inicjowaniu i podtrzymywaniu działań przybliżających jednostkę do jego osiągnięcia. Istotne jest tu podporządkowanie aktualnie realizowanemu celowi tych wszystkich aspektów Ja, w tym preferencji i potrzeb, które mogą być z nim niezgodne. Niepowodzenia w procesie samokontroli są więc przyczyną prokrastynacji unikowej czy, szerzej, behawioralnej.

Model Lazarusa i Folkman (Lazarus, Folkman, 1987; Doliński, Strelau, 2008) opisuje i wyjaśniania rolę procesów poznawczych leżących u podłoża prokrastynacji. Uwypukla on znaczenie niskiej samooceny i poczucia braku kompetencji oraz irracjonalnych przekonań dla angażowania się osób w zwlekanie. Jeśli jednostka ocenia, że posiadane przez nią zasoby są niewystarczające do rozwiązania problemu, doświadcza rosnącego napięcia, które może budzić pragnienie ucieczki z sytuacji, a w rezultacie skutkować odwlekaniem zadań wywołujących lęk. Model ten ukazuje prokrastynację jako nastawiony na emocje dysfunkcjonalny styl radzenia sobie. Zwlekanie ma tu charakter wzmocnienia negatywnego jest nagradzające, gdyż uwalnia, przynajmniej na pewien czas, od negatywnych emocji.

\section{Badania wlasne}

\section{Metoda}

$\mathrm{Na}$ potrzeby badania skonstruowany został liczący sześćdziesiąt trzy pozycje Kwestionariusz Zwlekania (KZ). Powstał on w wyniku połączenia czterech popularnych skal badających prokrastynację - Tuckman Procrastination Scale (TPS), Adult Inventory of 
Procrastination (AIP), General Procrastination Scale (GPS), Aitken Procrastination Inventory (API). Narzędzia te nie posiadają polskiego thumaczenia, adaptacji ani standaryzacji. Na użytek niniejszego badania przełożył je na język polski tłumacz Piotr Nowakowski.

Skala Prokrastynacji Tuckmana, stworzona przez Bruce'a W. Tuckmana w 1991 r., jest narzędziem bazującym na samoopisie, jednowymiarowym, dostarczającym ogólnego wskaźnika prokrastynacji akademickiej, rozumianej jako poziom zdolności do samoregulacji i kontroli harmonogramu zadań (Ferrari, Johnson, McCown, 1995). Kwestionariusz składa się z 16 pozycji ocenianych na czteropunktowej skali (od 1 - ,absolutnie tak nie postępuję" do 4 - „właśnie tak postępuję"). Cechuje się wysoką rzetelnością: $\alpha=0,86(\mathrm{n}=50)$ i $\alpha=0,90$ $(\mathrm{n}=183)$. Według Tuckmana prokrastynacja powodowana jest przez połączenie braku wiary w możliwość dobrego wykonania zadania, niezdolności do odraczania gratyfikacji oraz częstego przypisywania winy za życiowe niepowodzenia czynnikom zewnętrznym. Skala opisuje studentów, którzy marnują czas, spóźniają się i unikają zadań ocenianych jako nieprzyjemne.

Ogólna Skala Prokrastynacji Clarry’ego H. Lay’a jest narzędziem jednowymiarowym, powstałym w 1986 r. z połączenia dwóch liczących po 18 pozycji inwentarzy typu prawdafałsz, służących do badania zachowań akademickich. Obecna wersja składa się z 20 itemów mierzących zwlekanie w sytuacjach codziennych. Do oceny stosowana jest pięciostopniowa skala Likerta (od 1 - ,zdecydowanie nie dotyczy” do 5 - „zdecydowanie dotyczy”). Rzetelność skali według jej autora wynosi $\alpha=0,82$ (Lay, 1986, za: Ferrari, 1992), a rzetelność sprawdzana metodą test-retest wyniosła $\alpha=0,80$ (Ibidem). Lay podaje, że wyniki w skali korelują z niezorganizowaniem i spóźnianiem się oraz są niezależne od potrzeby osiągnięć, poziomu energii i poczucia własnej wartości.

Skonstruowany w 1989 r. Profil Prokrastynacji Człowieka Dorosłego Williama G. McCowna i Judith L. Johnson jest inwentarzem jednowymiarowym, liczącym 15 pozycji ocenianych na pięciopunktowej skali (od 1 - ,zdecydowanie się nie zgadzam” do 5 „zdecydowanie się zgadzam”). Rzetelność wewnętrzna według autorów wynosi $\alpha=0,79$, a rzetelność mierzona metodą test-retest $\mathrm{w}$ odstępie jednego miesiąca wyniosła $\alpha=0,71$ (Ferrari, 1992). Według McCowna i Johnson wysokie wyniki w skali korelują pozytywnie z nieefektywnym zarządzaniem czasem, a negatywnie z impulsywnością oraz nie korelują z depresją. Wyniki uzyskiwane przez osoby badane pozwalały przewidywać ich opóźnienia m. in. w płaceniu rachunków telefonicznych i wypełnianiu zeznań podatkowych. 
Profil Prokrastynacji Aitken został opracowany w 1982 r. przez Margaret E. Aitken na potrzeby jej dysertacji doktorskiej. Jego przeznaczeniem było zidentyfikowanie studentów o wysokim i niskim poziomie prokrastynacji. Inwentarz składa się z 19 pozycji ocenianych na pięciostopniowej skali Likerta (od 1 - „nieprawda” do 5 - „prawda”). Według autorki narzędzie odznacza się wysoką rzetelnością - $\alpha$ Cronbacha wyniosła 0,82. Mierzy prokrastynację motywowaną lękiem przed porażką i wrażliwością na awersyjność zadania (Paulitzki, 2010).

\section{Procedura badania}

Celem niniejszej pracy było skonstruowanie nowego kwestionariusza badającego prokrastynację oraz określenie jego wartości diagnostycznej.

W badaniu wzięło udział 160 osób (106 kobiet i 53 mężczyzn, jedna osoba nie podała płci) w wieku od 18 do 46 lat $\left(M=25,06, S D=5,38 ; M_{K}=25,16, S D_{K}=4,80 ; M_{M}=24,96\right.$, $\left.S D_{M}=6,43\right)$. Grupa była zróżnicowana ze względu na sytuację mieszkaniową, aktualne zajęcie, posiadanie rodzeństwa oraz zaangażowanie w związki.

Badanie przeprowadzono w okresie od listopada 2013 roku do lutego 2014 roku. Uczestników rekrutowano na dwóch uczelniach wrocławskich - Uniwersytecie Wrocławskim oraz Politechnice Wrocławskiej. Udział w badaniu wzięły również osoby, które wypełniły kwestionariusz zamieszczony w Internecie na forach poświęconych prokrastynacji lub na portalu społecznościowym Facebook.

Wszystkie obliczenia zostały wykonane z zastosowaniem pakietu statystycznego Statistica w wersji 10.

\section{Uzyskane wyniki}

Po przeprowadzeniu badań otrzymano wyniki w przedziale od 99 do 300 punktów. Średnia wyników surowych wyniosła $M=188,19(S D=47,99)$, mediana $M e=184,5$, moda $D=211$. Rozkład wyników istotnie odchylał się od rozkładu normalnego, co sprawdzono testem W Shapiro-Wilka ( $\mathrm{W}=0,97, \mathrm{p}=0,002$ ). Rozkład wyników był lekko prawoskośny i platykurtyczny. Po przeprowadzeniu standaryzacji rozkładu obliczono liczebności wyników niskich, średnich i wysokich. Liczba wszystkich obserwacji wyniosła $\mathrm{N}=160$, w tym 
23 wyniki niskie $(-2<\mathrm{z} \leq-1), 109$ wyników średnich $(-1<\mathrm{z} \leq 1), 25$ wyników wysokich $(1<\mathrm{z} \leq 2)$ oraz 3 wyniki bardzo wysokie $(2<\mathrm{z} \leq 3)$.

Pierwszym krokiem w kierunku konstrukcji kwestionariusza było przeprowadzenie eksploracyjnej analizy czynnikowej metodą głównych składowych ze znormalizowaną rotacją Biquartimax. Otrzymano 13 składowych głównych z wartością własną powyżej jedności, wyjaśniających łącznie 70,15\% wariancji. Na wykresie osypiska (zob. Rys. 1) wyodrębniały się wyraźnie dwa czynniki główne, wyjaśniające łącznie 45,29\% wariancji. Przyrost wariancji wyjaśnianej dla pierwszego czynnika wyniósł 37,83\% (wartość własna wyniosła 23,83), a dla drugiego 7,46\% (wartość własna wyniosła 4,70).

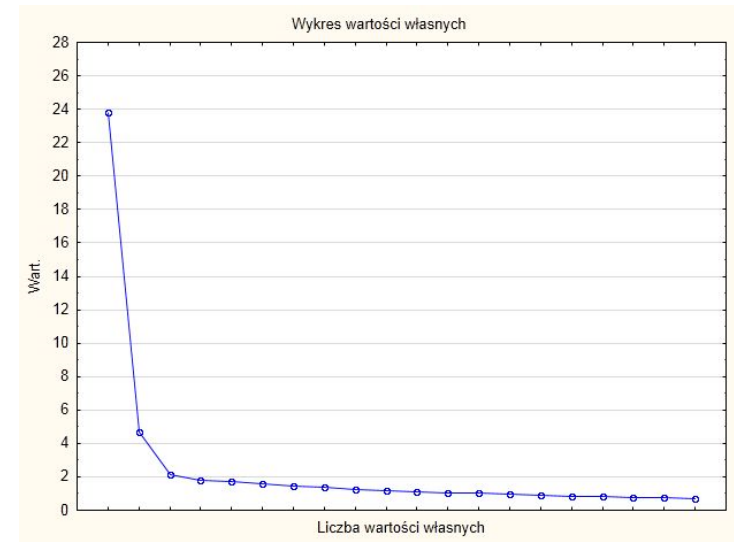

Rys. 1. Wykres osypiska

Cel kolejnego etapu analizy stanowiło zmniejszenie liczby twierdzeń. W pierwszym kroku do tworzonego kwestionariusza zostały włączone pozycje o wysokich ładunkach czynnikowych, czyli osiągających wartości powyżej 0,70 . W następnym kroku dodano te pozycje, których wartość ładunku czynnikowego okazała się wysoka, a zarazem różnica wartości ładunków między czynnikami 1 i 2 była duża. W ten sposób otrzymano pulę 45 pozycji testowych. Wyselekcjonowane pozycje oraz ich ładunki czynnikowe, przedstawia Tabela 1.

Tabela 1. Ładunki czynnikowe poszczególnych pozycji testowych wchodzących w skład głównych czynników. Pogrubioną czcionką oznaczono, w skład którego czynnika wchodzi dana pozycja.

\begin{tabular}{llrr}
\hline & Pozycja testowa & Czynnik 1 & Czynnik 2 \\
\hline 1 & $\begin{array}{l}\text { Wykorzystuję "okienka" w zajęciach, by wykonać zadania } \\
\text { przewidziane na wieczór. }\end{array}$ & $\mathbf{- 0 , 6 2 4 3 6}$ & 0,085276 \\
2 & W chorobliwy sposób marnotrawię czas. & $\mathbf{0 , 7 1 9 4 2}$ & 0,100400
\end{tabular}


3 Nie realizuję zadań na czas.

$\mathbf{0 , 7 1 4 3 3} 0,207914$

4 Potrafię znaleźć wymówkę, by czegoś nie zrobić.

$\mathbf{0 , 6 2 5 7 9} 0,080762$

5 Gdy obowiązują mnie terminy, czekam z pracą do ostatniej chwili.

6 Przystąpienie do realizacji zadania często zabiera mi wiele czasu.

7 Często odwlekam przez wiele dni nawet proste prace, których wykonanie nie zajmuje wiele czasu.

8 Za pracę zabieram się dopiero w ostatniej chwili.

$\mathbf{0 , 8 4 3 6 5} 0,097915$

$\mathbf{0 , 7 6 7 5 0} 0,050720$

$\mathbf{0 , 7 7 2 7 6} 0,053632$

$\mathbf{0 , 8 4 1 3 1} 0,135263$

9 Gdy zbliża się termin egzaminu, często przyłapuję się na realizowaniu innych zadań.

$10 \mathrm{~W}$ zeszłym roku poniosłem finansowe konsekwencje odkładania spraw na ostatnią chwilę.

11 W opinii moich przyjaciół i rodziny lubię zwlekać do ostatniej chwili.

12 Zazwyczaj realizuję wszystkie zadania, które wyznaczyłem sobie danego dnia.

13 Gdy jestem gdzieś umówiony, moi znajomi oczekują, że się nieco spóźnię.

14 Odkładam pracę nad poprawą moich nawyków.

15 Poświęcam wymagany czas nawet na nudne zadania takie, jak nauka.

16 Zazwyczaj rozpoczynam realizację zadań natychmiast po ich otrzymaniu.

17 Niepotrzebnie przeciągam realizację zadań, nawet wówczas, gdy są ważne.

18 Natychmiast przystępuję do realizacji niezbędnych prac.

19 Odczuwam wstyd z powodu odwlekania pracy, lecz nie skłania mnie to do działania.

20 Marnotrawię czas, ale nie potrafię na to nic poradzić.

21 Często odwlekam rozpoczęcie niezbędnych prac.

$\mathbf{0 , 6 4 1 9 1} 0,098322$

$\mathbf{0 , 5 9 6 3 1} 0,166784$

$\mathbf{0 , 7 3 4 6 8} \quad 0,196807$

$\mathbf{- 0 , 6 7 7 9 6}-0,068247$

$0,23362 \mathbf{0 , 7 5 7 8 5 2}$

$\mathbf{0 , 5 8 4 1 4} 0,085458$

$\mathbf{- 0 , 6 1 9 8 7} \quad 0,037351$

$\mathbf{- 0 , 6 4 4 4 8}-0,098051$

$\mathbf{0 , 7 5 9 9 2} 0,087747$

$\mathbf{- 0 , 6 7 6 2 2}-0,114226$

$\mathbf{0 , 7 2 4 8 6} 0,169589$

$\mathbf{0 , 7 8 6 3 7} 0,065210$

$\mathbf{0 , 8 1 8 0 2} 0,114471$

22 Tak długo odwlekam rozpoczęcie pracy, że często nie jestem w stanie jej skończyć w terminie.

23 Gdy muszę zrealizować ważny projekt, zabieram się do niego tak szybko, jak to możliwe.

24 Nie jestem w stanie przemóc się, by rozpocząć pracę nawet wówczas, gdy zdaję sobie sprawę z wagi zadania.

25 Potrafię przetrzymywać gotowe listy przez kilka dni, zanim je nadam.

26 Postępuję zgodnie z ustalonymi przez siebie planami.

$\mathbf{0 , 7 5 6 8 0} 0,175034$

$\mathbf{- 0 , 7 4 2 6 3} 0,006689$

$\mathbf{0 , 7 9 2 5 1} 0,131358$

$\mathbf{0 , 5 3 3 5 2} 0,102346$

$\mathbf{- 0 , 7 6 3 9 9}-0,061692$

$\mathbf{0 , 7 5 7 1 6} 0,075524$

27 Gdy zbliża się termin realizacji zadania, często tracę czas na inne sprawy.

$28 \mathrm{Na}$ zebraniach zazwyczaj pojawiam się przed ich

$-0,14997 \quad \mathbf{- 0 , 7 9 8 7 3 8}$ rozpoczęciem. 
29 Często spóźniam się na spotkania i zebrania.

$$
\begin{array}{rr}
0,26394 & \mathbf{0 , 8 6 8 0 5 0} \\
-0,24056 & \mathbf{- 0 , 8 5 9 7 6 6} \\
\mathbf{0 , 7 6 1 7 1} & -0,014645 \\
\hline \mathbf{- 0 , 6 7 2 4 1} & -0,282172 \\
\mathbf{- 0 , 6 6 9 5 3} & -0,253657
\end{array}
$$

30 Wychodzę wcześniej, aby nie spóźniać się na spotkania.

31 Często zdarza mi się stwierdzić "zrobię to jutro".

32 Ważne zadania kończę przed terminem.

33 Często kończę pracę wcześniej niż jest to wymagane.

34 Przekładanie spraw na jutro - to nie w moim stylu.

$\mathbf{- 0 , 7 4 9 1 1}-0,046741$

35 Gdy staję w obliczu trudnego problemu, zastanawiam się, jak go odsunąć w czasie.

36 Nie odwlekam pracy, gdy wiem, że musi ona zostać wykonana.

37 Punktualnie stawiam się na większość spotkań.

$\mathbf{0 , 6 4 1 3 2} 0,046356$

$\mathbf{- 0 , 7 5 6 5 6}-0,093030$

$-0,28753 \quad \mathbf{- 0 , 8 5 8 3 4 8}$

38 Często zdarza mi się wykonywać zadania na gwałt, gdy grozi przekroczenie terminu.

39 Często łapię się na wykonywaniu czynności, które zamierzałem wykonać wiele dni wcześniej.

$40 \mathrm{Z}$ opóźnieniem zabieram się za czynności, których nie lubię.

$\mathbf{0 , 5 8 8 1 1} 0,087298$

$\mathbf{0 , 6 2 8 2 9} 0,054566$

$\mathbf{0 , 5 8 1 2 7} \quad 0,031741$

41 Zazwyczaj wykonuję wszystkie oczekujące zadania przed udaniem się na wieczorny relaks.

42 Zazwyczaj punktualnie przychodzę na zajęcia.

$\mathbf{- 0 , 7 9 4 9 1} 0,001386$

43 Jestem punktualniejszy niż większość znanych mi osób.

$-0,28649 \quad \mathbf{- 0 , 8 0 9 7 6 4}$

$-0,23631 \quad \mathbf{- 0 , 8 2 9 4 5 2}$

44 Terminowo wywiązuję się ze zobowiązań dzięki $\quad \mathbf{- 0 , 7 7 5 6 8} \quad-0,156069$ systematycznej pracy.

45 Obiecuję sobie, że coś zrobię, lecz następnie opóźniam $\quad \mathbf{0 , 8 4 3 0 2} \quad 0,058188$ rozpoczęcie pracy.

$\mathrm{Na}$ wyodrębnionych $\mathrm{w}$ ten sposób pozycjach przeprowadzono - oddzielnie dla każdego czynnika - hierarchiczną analizę skupień z wykorzystaniem metody pełnego wiązania i kwadratu odległości euklidesowej jako miary odległości. Analizę tę powtarzano kilkakrotnie w celu usunięcia pozycji odstających, niepasujących do pozostałych stwierdzeń oraz uzyskania skupień jak najbardziej jednorodnych treściowo. Otrzymano w ten sposób pięć skupień - cztery w obrębie czynnika 1 i jedno tworzące spójny wewnętrznie czynnik 2. Pozycje testowe wchodzące w skład poszczególnych skupień przedstawia Tabela 2.

Tabela 2. Pozycje testowe wchodzące w skład poszczególnych skupień (podskale treściowe)

\section{Nr skupienia Pozycje testowe}

Skupienie 1 1. Wykorzystuję "okienka" w zajęciach, by wykonać zadania przewidziane na wieczór. 
2. Zazwyczaj rozpoczynam realizację zadań natychmiast po ich otrzymaniu.

3. Często kończę pracę wcześniej niż jest to wymagane.

4. Zazwyczaj wykonuję wszystkie oczekujące zadania przed udaniem się na wieczorny relaks.

5. Terminowo wywiązuję się ze zobowiązań dzięki systematycznej pracy.

6. Przekładanie spraw na jutro - to nie w moim stylu.

Skupienie 2 1. Zazwyczaj realizuję wszystkie zadania, które wyznaczyłem sobie danego dnia.

2. Postępuję zgodnie z ustalonymi przez siebie planami.

3. Poświęcam wymagany czas nawet na nudne zadania takie, jak nauka.

4. Natychmiast przystępuję do realizacji niezbędnych prac.

5. Gdy muszę zrealizować ważny projekt, zabieram się do niego tak szybko, jak to możliwe.

6. Ważne zadania kończę przed terminem.

7. Nie odwlekam pracy, gdy wiem, że musi ona zostać wykonana.

Skupienie 3 1. W chorobliwy sposób marnotrawię czas.

2. Marnotrawię czas, ale nie potrafię na to nic poradzić.

3. Gdy staję w obliczu trudnego problemu, zastanawiam się, jak go odsunąć w czasie.

4. Nie realizuję zadań na czas.

5. Tak długo odwlekam rozpoczęcie pracy, że często nie jestem w stanie jej skończyć w terminie.

6. W opinii moich przyjaciół i rodziny lubię zwlekać do ostatniej chwili.

7. Nie jestem w stanie przemóc się, by rozpocząć pracę nawet wówczas, gdy zdaję sobie sprawę $\mathrm{z}$ wagi zadania.

8. Gdy zbliża się termin realizacji zadania, często tracę czas na inne sprawy.

Skupienie 4 1. Potrafię znaleźć wymówkę, by czegoś nie zrobić.

2. Gdy zbliża się termin egzaminu, często przyłapuję się na realizowaniu innych zadań.

3. Gdy obowiązują mnie terminy, czekam z pracą do ostatniej chwili.

4. Za pracę zabieram się dopiero w ostatniej chwili.

5. Przystąpienie do realizacji zadania często zabiera mi wiele czasu.

6. Obiecuję sobie, że coś zrobię, lecz następnie opóźniam rozpoczęcie pracy.

7. Często odwlekam przez wiele dni nawet proste prace, których wykonanie nie zajmuje wiele czasu.

8. Niepotrzebnie przeciągam realizację zadań, nawet wówczas, gdy są ważne.

9. Często odwlekam rozpoczęcie niezbędnych prac.

10. Odczuwam wstyd z powodu odwlekania pracy, lecz nie skłania mnie to do działania.

11. Często zdarza mi się wykonywać zadania na gwałt, gdy grozi przekroczenie terminu.

12. Często łapię się na wykonywaniu czynności, które zamierzałem wykonać wiele dni wcześniej. 
Skupienie 5 1. Gdy jestem gdzieś umówiony, moi znajomi oczekują, że się nieco spóźnię.

2. Często spóźniam się na spotkania i zebrania.

3. Na zebraniach zazwyczaj pojawiam się przed ich rozpoczęciem.

4. Wychodzę wcześniej, aby nie spóźniać się na spotkania.

5. Punktualnie stawiam się na większość spotkań.

6. Zazwyczaj punktualnie przychodzę na zajęcia.

7. Jestem punktualniejszy niż większość znanych mi osób.

Pozycje tworzące skupienie 1 koncentrują się wokół organizacji czasu i systematyczności pracy. Diagnozują one ewentualne trudności w rozpoczynaniu lub kończeniu zadań, umiejętność planowania działań, zagospodarowywania wolnych chwil w celu optymalnego wykorzystania czasu i organizacji dziennej aktywności. Skupienie 2 zawiera pozycje akcentujące rolę woli w działaniu - samokontroli i samostanowienia, umiejętności wyznaczania sobie celów, układania planów, hierarchizacji zadań, nadawania różnych priorytetów działaniom. Skupienie 3 tworzą itemy badające świadomość prokrastynacji i wynikający z niej dyskomfort - zdawanie sobie sprawy z istnienia problemu i jego wagi (także na skutek społecznych informacji zwrotnych - uwag ze strony innych ludzi), poczucie braku siły do przeciwstawienia się irracjonalnemu zwlekaniu. Skupienie 4 dotyczy osobowościowego wymiaru zwlekania, uznania prokrastynacji za cechę charakteru kładzie nacisk na stałość przejawiania się tego wzorca zachowania w funkcjonowaniu osoby w różnych dziedzinach życia i rodzajach aktywności. Skupienie 5 określa punktualność w relacjach interpersonalnych.

Powstały w wyniku przeprowadzonych analiz Kwestionariusz Zwlekania umożliwia ogólną ocenę poziomu prokrastynacji oraz stworzenie indywidualnych profilów zwlekania na bazie pięciu podskal treściowych - 1) organizacji czasu i systematyczności pracy (OS), 2) siły woli (SW), 3) świadomości prokrastynacji (ŚP), 4) zwlekania ujmowanego jako stała cecha (C), 5) niepunktualności (NP). Jest to skala dwuczynnikowa, obejmująca złożony czynnik prokrastynacji behawioralnej i czynnik niepunktualności. Wysokie wyniki w podskalach 1-4 wskazują na tendencję do prokrastynowania, a wysokie wyniki w podskali 5 na niepunktualność; niskie wyniki wskazują odpowiednio na słabe skłonności do zwlekania i punktualność.

W kolejnym kroku test poddano analizie rzetelności. Współczynnik zgodności wewnętrznej a Cronbacha dla całego Kwestionariusza Zwlekania wyniósł 0,971, a dla poszczególnych jego podskal odpowiednio: dla podskali OS (12 pozycji) - 0,937, dla 
podskali SW (8 pozycji) - 0,923, dla podskali ŚP (6 pozycji) - 0,864, dla podskali C (7 pozycji) - 0,897 i dla podskali NP (7 pozycji) - 0,945. Dla porównania obliczono także współczynnik zgodności wewnętrznej $\alpha$ Cronbacha dla skal wyjściowych; wyniósł on odpowiednio: dla skali TPS - 0,944, dla skali API - 0,913, dla skali GPS - 0,904 i dla skali AIP $-0,843$.

Obliczono również korelacje Kwestionariusza Zwlekania ze skalami wyjściowymi. Najsilniej korelował on ze skalą API $(r=0,97)$, nieco słabiej ze skalami GPS $(r=0,95)$ i TPS $(\mathrm{r}=0,94)$, a najsłabiej ze skalą AIP $(\mathrm{r}=0,87)$.

Następnie na badanej grupie została przeprowadzona analiza skupień metodą $k$-średnich z wykorzystaniem podskal treściowych. W jej wyniku uzyskano trzy skupienia osób o różnym nasileniu zwlekania i odmiennych profilach prokrastynacji. Rezultaty analizy przedstawia Rysunek 2.

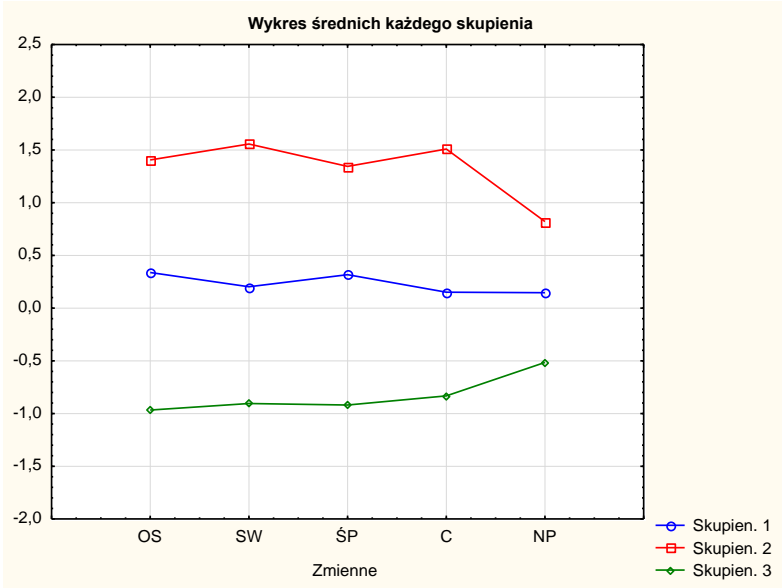

Rys. 2. Profile prokrastynacji uzyskane w wyniku analizy skupień metodą $k$-średnich z wykorzystaniem podskal treściowych

Osoby tworzące skupienie 1 prezentują umiarkowany poziom prokrastynacji i niepunktualności. Ich trudności wiążą się głównie z organizacją czasu i systematycznością pracy. Badanych z tej grupy cechuje relatywnie wysoka świadomość zwlekania i silna wola, by mu się przeciwstawiać. Prokrastynacja przejawia się u nich jedynie w niektórych dziedzinach życia lub pojawia się sporadycznie. Niepunktualność utrzymuje się na względnie niskim poziomie. Można przypuszczać, że są to osoby, które zdają sobie sprawę z problemu i starają się go kontrolować.

Skupienie 2 to ludzie o najsilniejszych tendencjach do prokrastynacji i niepunktualności. Ich trudności wynikają głównie z braku silnej woli i ograniczonej świadomości zwlekania. Prokrastynacja obejmuje u nich wiele dziedzin życia i przejawia się 
często. Badani ci uważają, że nie mają szczególnych problemów z organizacją czasu i systematycznością pracy. Ich trudności w najmniejszym stopniu obejmują punktualność.

Skupienie 3 tworzą osoby o niskim poziomie prokrastynacji. Profil ten jest względnie wyrównany. Badani z tej grupy są systematyczni i dobrze zorganizowani. Jeśli zdarza im się zwlekać, mają tego świadomość, a trudności z wywiązaniem się z zadania przypisują sobie niedostatkom siły woli lub charakteru. Relatywnie największą trudność sprawia im punktualność.

W następnym kroku dokonano charakterystyki poszczególnych skupień ze względu na mierzone zmienne demograficzne - płeć, wiek, aktualne zajęcie, sytuację mieszkaniową w chwili badania, zaangażowanie w związki, posiadanie rodzeństwa.

Aby zbadać istotności różnic liczebności w zakresie wartości poszczególnych zmiennych w obrębie skupień oraz pomiędzy skupieniami przeprowadzono testy różnicy między dwoma wskaźnikami struktury. Wykazały one, że skupienie 1 charakteryzuje się przewagą kobiet $\mathrm{w}$ stosunku do mężczyzn. Średnia wieku w tym skupieniu wyniosła $M=24,76$ lat $(S D=0,67)$. Osoby je tworzące głównie uczą się lub studiują i jest to przewaga istotna względem pozostałych typów zajęcia $(\mathrm{p}<0,05)$. Większość badanych mieszka ze współlokatorami, aktualnie nie jest zaangażowana w żadnym związku i posiada starsze lub młodsze rodzeństwo (różnice te nie były jednak statystycznie istotne). W skupieniu 2 kobiet jest dwukrotnie więcej niż mężczyzn. Średnia wieku wyniosła $M=25,26$ lat $(S D=0,99)$. Przeważają osoby uczące się, mieszkające ze współlokatorami, będące w długotrwałych związkach lub niezaangażowane w żaden związek i osoby posiadające młodsze rodzeństwo. Żadne różnice nie były istotne statystycznie. W skupieniu 3 występuje istotna przewaga kobiet w stosunku do mężczyzn $(\mathrm{p}=0,001)$. Średnia wieku wyniosła $M=25,25$ lat $(S D=0,66)$. Dominują osoby uczące się (przewaga liczebna w stosunku do osób pracujących jest bliska istotności statystycznej, $\mathrm{p}=0,06$ ), mieszkające ze współlokatorami, zaangażowane w długotrwałe związki (różnica w stosunku do osób zamężnych/żonatych jest bliska istotności statystycznej, $\mathrm{p}=0,05)$ i posiadające starsze lub młodsze rodzeństwo.

Istotnie różniły się między sobą jedynie skupienia 2 i 3 pod względem dwóch zmiennych - płci i zaangażowania w związki. W skupieniu 3 było istotnie więcej kobiet $(\mathrm{p}<0,05)$ oraz osób zaangażowanych w długotrwałe związki $(\mathrm{p}<0,05)$.

\section{Dyskusja}


Intencją pracy było stworzenie kwestionariusza umożliwiającego oszacowanie poziomu prokrastynacji. W tym celu przeprowadzono na grupie 160 ochotników badanie wstępną, liczącą 63 pozycje, wersją skali. Uzyskane wyniki poddano analizie czynnikowej, wyodrębniając dwa czynniki główne. Na pozycjach wchodzących w skład obu czynników przeprowadzono następnie hierarchiczną analizę skupień. Analiza treści otrzymanych klasterów wyłoniła pięć skupień, które utworzyły podskale treściowe kwestionariusza: OS organizacja czasu i systematyczność pracy, SW - siła woli, ŚP - świadomość prokrastynacji, C - zwlekanie jako cecha, NP - niepunktualność. Suma wyników wszystkich podskal stanowi wynik końcowy - ogólną ocenę poziomu prokrastynacji. Powstała skala jest zatem skalą dwuczynnikową, obejmującą złożony czynnik prokrastynacji (cztery pierwsze podskale) i czynnik punktualności (podskala NP). Umożliwia ogólną ocenę poziomu zwlekania badanych osób oraz stworzenie indywidualnych profilów prokrastynacji na podstawie skal treściowych. Kwestionariusz uzyskał zadowalająco wysoki współczynnik zgodności wewnętrznej alfa Cronbacha wynoszący 0,971.

Podstawę kwestionariusza stanowiły cztery skale, z czego dwie - General Procrastination Scale (GPS) i Adult Inventory of Procrastination (AIP) stosowane są do badania prokrastynacji codziennej, a dwie kolejne - Tuckman Procrastination Scale (TPS) i Aitken Procrastination Inventory (API) - do badania prokrastynacji akademickiej. Kwestionariusz Zwlekania najsilniej koreluje ze skalą Aitken $(r=0,97)$.

Kwestionariusz Zwlekania zawiera pięć podskal treściowych - cztery w obrębie czynnika pierwszego (podskale OS, SW, ŚP i C) i jedną w obrębie czynnika drugiego (podskala NP). Podskala OS określa umiejętności w zakresie optymalnego wykorzystania czasu, organizacji i planowania czynności. Podskala SW odzwierciedla zdolność do wyznaczania sobie celów oraz podporządkowywania im innych, alternatywnych dążeń. Umiejętności te odpowiadają samokontroli w koncepcji Kuhla. Podskala ŚP pozwala ocenić poziom dyskomfortu związanego ze zwlekaniem - ukazuje subiektywny odbiór i świadomość problemu. Podskala $\mathrm{C}$ opisuje stałość zachowania w czasie, w różnych dziedzinach życia i w odniesieniu do różnego rodzaju zadań. Podskala NP diagnozuje niepunktualność w relacjach interpersonalnych. Taka konstrukcja kwestionariusza odróżnia go od dotychczas stosowanych narzędzi. Jej zaletą jest to, że pozwala nie tylko na oszacowanie poziomu prokrastynacji, lecz także na wielowymiarowy opis trudności będących udziałem osób badanych i analizę konfiguracji wywołujących je czynników. 
Przeprowadzono badanie sprawdzające wartość diagnostyczną skonstruowanej skali. Zastosowanie analizy skupień metodą $k$-średnich na wynikach uzyskanych przez osoby badane $\mathrm{w}$ podskalach treściowych doprowadziło do wyłonienia trzech grup różniących się poziomem prokrastynacji i profilami zwlekania. Trudności osób o najsilniejszych skłonnościach do odkładania okazały się wynikiem głównie braku samokontroli (silnej woli) i ograniczonej świadomości istnienia problemu, co uwidacznia się m. in. w tym, że uważają się za dość dobrze zorganizowane. Trudności z terminową realizacją zadań stanowią u nich stały wzorzec zachowania, ale, co ciekawe, w stosunkowo niewielkim stopniu dotyczą punktualności. Drugą grupę stanowią badani o umiarkowanym poziomie prokrastynacji. Cechuje ich relatywnie wysoka świadomość odkładania i silna wola, które najprawdopodobniej wspólnie prowadzą do ograniczenia zakresu występowania zwlekania. Ich problemy z terminowym wywiązywaniem się ze zobowiązań wiążą się głównie ze złą organizacją czasu i niepowodzeniami w zakresie planowania. Trzecią grupę tworzą osoby o niskim poziomie prokrastynacji - systematyczne i dobrze zorganizowane. Mają wysoką świadomość zwlekania, a jego przyczyn szukają w sobie - w niedostatkach samokontroli lub słabości charakteru. Relatywnie największą trudność sprawia im punktualne przychodzenie na umówione spotkania. Należy podkreślić, że analiza profilów, zawierająca związki przyczynowo-skutkowe, stanowi jedynie domysł, który powinien być potwierdzony $\mathrm{w}$ rozmowie $\mathrm{z}$ osobą badaną, jeśli ocena prokrastynacji miałaby zostać wykorzystana do celów innych niż statystyki naukowe, np. do celów klinicznych.

Profile tworzone z wykorzystaniem podskal treściowych ukazują pewne wzorce prokrastynacji. Stanowią one konfigurację elementów kluczowych dla zwlekania, odzwierciedlają mocne i słabe strony badanych jednostek, umożliwiając wgląd w potencjalne przyczyny odkładania zadań oraz zasoby, które mogą być wykorzystane do jego ograniczenia. Wzorce te są odmienne od tych opisanych przez Kanusa - tworzone na innej zasadzie i mające różną użyteczność. U Knausa każdy ze stylów prokrastynacji zdominowany jest przez jeden aspekt - określoną przyczynę lub typ zadań, ma więc charakter jednowymiarowy, a zwlekanie może przebiegać według pojedynczego wzorca lub mieć postać mieszaną. Model ten koncentruje się na trudnościach, pokazuje jak przejawia się prokrastynacja i czym jest powodowana, nie uwzględnia natomiast mocnych stron osób zwlekających oraz związków pomiędzy czynnikami wywołującymi odkładanie, jak ma to miejsce w przypadku wielowymiarowych wzorców tworzonych z wykorzystaniem podskal Kwestionariusza Zwlekania. 
Dwuczynnikowa konstrukcja skali odróżnia ją od dotychczas stosowanych, jednoczynnikowych narzędzi. Popularne klasyfikacje prokrastynacji, takie jak model Ferrariego czy Knausa, traktują niepunktualność jako jeden z aspektów prokrastynacji. Przeprowadzone badania wskazują jednak na jej odrębność. Analiza profilów osób prokrastynujących i niemających skłonności do zwlekania pozwala przypuszczać, że grupy te różnią się podejściem do czasu. Badani o wysokich wynikach w zakresie prokrastynacji, uzyskiwali stosunkowo niższe wyniki w skali punktualności i odwrotnie, ci badani, których cechowała niska prokrastynacja, przyznawali się do problemów z punktualnością. Różnice te można wyjaśnić odmiennym stosunkiem do czasu u osób zwlekających i niezwlekających. Dla prokrastynatorów czas jest szczególnie istotny, wobec czego mają oni wysoką jego świadomość. Stałe monitorowanie upływających godzin i minut sprzyja $z$ kolei punktualności. Dla osób, które nie odkładają wykonywania zadań, pracują w równym tempie i na bieżąco wywiązują się $\mathrm{z}$ podjętych zobowiązań, pilnowanie czasu ma znaczenie drugorzędne, wobec czego są one prawdopodobnie mniej uważne na jego upływ, co w pewnych warunkach może powodować trudności z punktualnością.

Stosunek do czasu i jego istotność w życiu osób prokrastynujących i nieprokrastynujących lepiej wyjaśnia niepunktualność drugich niż względnie wysoką punktualność pierwszych. Różnicę w wynikach w zakresie zwlekania i punktualności u prokrastynatorów może tłumaczyć obecność moderatora, który nasila nieterminowość w odniesieniu do wywiązywania się z zadań, a osłabia ją w stosunku do przychodzenia na umówione spotkania. W świetle badań Solomon i Rothblum (1984) oraz Schouwenburga (1992), prokrastynacja akademicka powodowana jest głównie lękiem przed porażką oraz spostrzeganą awersyjnością zadań związanych z nauką. Wydaje się, że oba te czynniki mogą wyjaśniać uzyskane wyniki. Lęk przed zadaniami weryfikującymi kompetencje najprawdopodobniej nie ujawnia się w sytuacjach spotkań towarzyskich oraz samej obecności na zajęciach akademickich, nie wpływa zatem na punktualność. Spotkania i zajęcia mogą być także spostrzegane przez studentów jako aktywności przyjemniejsze niż pisanie prac zaliczeniowych lub nauka, wobec czego badani zwlekają w odniesieniu do nich znacznie mniej. Zarówno lęk przed porażką, jak i awersyjność zadania wydają się dobrymi moderatorami ujawniania się nieterminowości, ich rzeczywiste znaczenie wymaga jednak dalszych badań.

Co jednak sprawia, że niepunktualność prokrastynatorów jest (bezwzględnie) większa niż osób nieprokrastynujących? Jaki czynnik odpowiada zarówno za trudności 
z systematycznością pracy, rozpoczynaniem jej i kończeniem w terminie, jak również za spóźnianie się na umówione spotkania? Wśród przyczyn prokrastynacji akademickiej wymienia się $\mathrm{m}$. in. złe zarządzanie czasem, trudności z podejmowaniem decyzji, sprzeciw wobec kontroli i brak pewności siebie (za: Solomon i Rothblum, 1984). Każda z nich, jak również cechy osobowości nie związane wyłącznie $\mathrm{z}$ tym rodzajem zwlekania, a charakterystyczne dla osób zwlekających, np. neurotyczność (zwłaszcza depresyjność, nadmierny samokrytycyzm, nadwrażliwość), sumienność (obowiązkowość, samodyscyplina) czy niskie poczucie własnej wartości, mogą potencjalnie wyjaśniać uzyskane wyniki. Dalsze badania powinny być poświęcone weryfikacji wartości eksplanacyjnej tych zmiennych.

Ostatnio coraz więcej badaczy wiąże prokrastynację $\mathrm{z}$ doświadczaniem czasu, zwłaszcza z orientacjami temporalnymi - zorientowaniem na przeszłość, teraźniejszość lub przyszłość (Specter, Ferrari, 2000; Jackson, Fritch, Nagasaka, Pope, 2003) i chronotypami preferowaniem aktywności porannej lub wieczornej (Hess, Sherman, Goodman, 2000). $\mathrm{Z}$ badań wynika, że skłonność do prokrastynacji koreluje pozytywnie $\mathrm{z}$ orientacją na przeszłość, a negatywnie z orientacją na przyszłość. Osoby zwlekające koncentrują się na minionych wydarzeniach, zwłaszcza negatywnych, niewiele uwagi poświęcając przyszłym celom. W stosunku do teraźniejszości przyjmują postawę hedonistyczną lub fatalistyczną. Z kolei w odniesieniu do chronotypów stwierdzono, że prokrastynacja, zwłaszcza akademicka, łączy się z preferowaniem aktywności wieczornej. Wyniki opisane w niniejszej pracy wpisują się $\mathrm{w}$ ten nurt badań. W przyszłości warto byłoby sprawdzić, czy świadomość czasu rzeczywiście różni się u osób o różnych poziomach prokrastynacji.

Płeć, wiek, aktualne zajęcie, sytuacja mieszkaniowa, posiadanie rodzeństwa i zaangażowanie w związki okazały się nieistotne dla poziomu prokrastynacji. Jest to wynik spójny z dotychczas uzyskiwanymi. Wielu badaczy próbuje powiązać zwlekanie z różnymi zmiennymi demograficznymi (Ferrari, O'Callaghan, Newbegin, 2005), jednak do tej pory udało się to wyłącznie $\mathrm{w}$ odniesieniu do płci i wieku, a zaobserwowane zależności występowały jedynie w niektórych badaniach i były wzajemnie niezgodne (Steel, 2007).

Zmienne demograficzne zostały wykorzystane do charakterystyki skupień osób o różnych profilach zwlekania. W skupieniu 1, w którym znalazły się osoby o umiarkowanym poziomie prokrastynacji, dominowały osoby uczące się. Skupienie 2 - osób o najwyższym poziomie prokrastynacji, okazało się najbardziej zrównoważone pod względem wszystkich zmiennych demograficznych. W skupieniu 3, czyli grupie osób o najniższym poziomie zwlekania, przeważały osoby uczące się i zaangażowane w długotrwałe związki. Choć 
opisane różnice były istotne lub bliskie istotności statystycznej, wynikają najprawdopodobniej z doboru próby (osoby uczące się stanowiły ponad połowę wszystkich badanych, a osoby w długotrwałych związkach - 40 procent) i nie pozwalają na wyjaśnienie różnic w profilach i ogólnym poziomie prokrastynacji. Ponieważ obecne badanie przeprowadzone zostało na próbie incydentalnej, w przyszłości warto byłoby zweryfikować uzyskane wyniki na grupie bardziej reprezentatywnej.

Skonstruowana skala wymaga przeprowadzenia oceny trafności. Pozycje kwestionariusza zgodne są z powszechnie stosowaną definicją prokrastynacji akademickiej, co pozwala sądzić, że kryterium trafności wewnętrznej zostało spełnione. W kolejnych badaniach można podjąć próbę sprawdzenia także trafności zewnętrznej.

Jeśli użyteczność Kwestionariusza Zwlekania zostałaby potwierdzona w dalszych badaniach, ważne byłoby dokonanie standaryzacji, umożliwiające opracowanie graficznego sposobu prezentacji indywidualnych wyników. Stworzenie metody wizualizacji wyników jest wskazane, gdyż profil staje się wówczas bardziej czytelny i łatwiejszy do oceny.

\section{Literatura cytowana}

Beswick, G., Rothblum, E. D., Mann, L. (1988). Psychological Antecedents of Student Procrastination. Australian Psychologist, 23 (2), 207-217.

Díaz-Morales, J. F., Cohen, J. R., Ferrari J. R. (2008). An integrated view of personality styles related to avoidant procrastination. Personality and Individual Differences, 45 (6), 554-558.

Ferrari, J. R. (1992). Psychometric Validation of Two Procrastination Inventories for Adults: Arousal and Avoidance Measures. Journal of Psychopathology and Behavioral Assessment, 14 (2), 97 110.

Ferrari, J. R., Barnes, K. L., Steel, P. (2009). Life Regrets by Avoidant and Arousal Procrastinators. Why Put Off Today What You Will Regret Tomorrow? Journal of Individual Differences, 30(3), 163-168.

Ferrari, J. R., Johnson, J. L., McCown, W. G. (1995). Procrastination and Task Avoidance. Theory, Research, and Treatment. New York: Plenum Press.

Ferrari, J. R., O'Callaghan, J., Newbegin, J. (2005). Prevalence of Procrastination in the United States, United Kingdom, and Australia: Arousal and Avoidance Delays among Adults. North American Journal of Psychology, 7 (1), 1-6.

Ferrari, J. R., Pychyl, T. A. (2012). "If I Wait, My Partner Will Do It": The Role of Conscientiousness as a Mediator in the Relation of Academic Procrastination and Perceived Social Loafing. North American Journal of Psychology, 14 (1), 13-24. 
Freeman, E. K., Cox-Fuenzalida, L., Stoltenberg, I. (2011). Extraversion and Arousal Procrastination: Waiting for the Kicks. Current Psychology: A Journal for Diverse Psychological Issues, 30(4), 375-382.

Hess, B., Sherman, M. F., Goodman, M. (2000). Eveningness Predicts Academic Procrastination: The Mediating Role of Neuroticism. Journal of Social Behavior and Personality, 15 (5), 61-74.

Hezjod (2011). Prace i dnie. Pobrano z: http://kulturaantyczna.files.wordpress.com/2011/12/hezjodprace-i-dnie.pdf.

Jackson, T., Fritch, A., Nagasaka, T., Pope, L. (2003). Procrastination and Perceptions of Past, Present, and Future. Individual Diferences Research, 1 (1), 17-28.

Kadzikowska-Wrzosek, R. (2010). Wolna wola w świetle badań współczesnej psychologii nad procesami samoregulacji i samokontroli. Psychologia Społeczna, 4 (15), 330-344.

Knaus, W. J. (2007). Nie odkładaj spraw na później. Jak sobie radzić z tą zgubną skłonnością. Przeł. O. Waśkiewicz. Warszawa: Jacek Santorski \& Co Agencja Wydawnicza.

Lazarus, R. S., Folkman, S. (1987). Transactional theory and research on emotions and coping. European Journal of Personality, 1 (3), 141-169.

Mann, L., Janis, I. L., Chaplin R. (1969). Effects of Anticipation of Forthcoming Information on Decisional Processes. Journal of Personality and Social Psychology, 11 (1), 10-16.

Milgram, N. A., Sroloff, B., Rosenbaum, M. (1988). The Procrastination of Everyday Life. Journal of Research in Personality, 22 (2), 197-212.

Milgram, N., Marshevsky, S., Sadeh, C. (1995). Correlates of Academic Procrastination: Discomfort, Task Aversiveness, and Task Capability. Journal of Psychology, 129 (2), 145-155.

Milgram, N., Tenne, R. (2000). Personality Correlates of Decisional and Task Avoidant Procrastination. European Journal of Personality, 14 (2), 141-156.

Orellana-Damacela, L. E., Tindale, R. S., Suárez-Balcázar, Y. (2000). Decisional and Behavioral Procrastination: How They Relate to Self-Discrepancies. Journal of Social Behavior and Personality, 15 (5), 225-238.

Paulitzki, J. R. (2010). Procrastination as Self-Regulatory Failure. Habitual Avoidance and Inhibitory Control Moderate the Intention-Behaviour Relation for Unpleasant Tasks (Dysertacja doktorska, University of Waterloo, 2010). Pobrano z: https://uwspace.uwaterloo.ca/bitstream/handle/10012/5374/Paulitzki_Jeff.pdf?sequence=3.

Schouwenburg, H. C. (1992). Procrastinators and fear of failure: an exploration of reasons for procrastination. European Journal of Personality, 6 (3), 225-236.

Solomon, L. J., Rothblum, E. D. (1984). Academic Procrastination: Frequency and CognitiveBehavioral Correlates. Journal of Counseling Psychology, 31 (4), 503-509.

Specter, M. H., Ferrari, J. R. (2000). Time Orientations of Procrastinators: Focusing on the Past, Present, or Future? Journal of Social Behavior and Personality, 15 (5), 197-202.

Steel, P. (2007). The Nature of Procrastination: A Meta-Analytic and Theoretical Review of Quintessential Self-Regulatory Failure. Psychological Bulletin, 133 (1), 65-94. 
Steel, P. (2010). Arousal, avoidant and decisional procrastinatinators: Do they exist? Personality and Individual Differences, 48 (8), 926-934.

Strelau, J., Doliński, D. (2008). Psychologia. Podręcznik akademicki. T. 1 i 2. Gdańsk: Gdańskie Wydawnictwo Psychologiczne. 